\title{
Peranan Penanaman Modal Asing Sebagai Upaya Peningkatan Petumbuhan Ekonomi di Sumatera Selatan Menuju Sumatera Selatan Maju
}

\author{
Dea Justicia Ardha* \\ Fakultas Hukum Universitas Muhammadiyah Palembang \\ *Correspondence email: deajusticia14@gmail.com
}

\begin{abstract}
Abstrak. Berkembangnya perekonomian suatu negara, terutama negara berkembang seperti Indonesia dan daerah pada khususnya dapat dilihat dari tingkat pertumbuhan penanaman modal asing. Kesejahteraan sosial masyarakat dipengaruhi oleh kemampuan ekonomi, agar meningkatkannya pendapatan secara adil dan merata. Pemerintah Provinsi Sumatera Selatan melakukan upaya untuk menarik investor asing, yang diharapkan dapat menimbulkan dampak positif bagi pengembangan dunia usaha dalam rangka memacu pertumbuhan dunia usaha daerah, misalnya memajukan industri kerajinan dan UMKM untuk peningkatan ekonomi kerakyatan guna pemerataan kesejahteraan rakyat di Sumatera Selatan menuju Sumatera Selatan maju.
\end{abstract}

Kata kunci: Penanaman Modal Asing (PMA); Pertumbuhan Ekonomi

\begin{abstract}
The economic development of a country, especially the developing country such as Indonesia and the regions in particular are largely determined by the growth rate of foreign investment. The social welfare of the community is strongly influenced by economic capacity to increase income fairly and evenly. The goverment of South Sumatera provinsial is also making efforts to attract investors, especially foreign investors to carry act in investment activities in South Sumatera, which as expected to have positive impact or development of the regional business in order to spur the growth of regional business, for example to advance the handicraft industry and micro, small and medium enterpires (MSME/UMKM) to increase people's economy which will lead to increase and aqual distribution of people's welfare in south sumatera towards andvanced South Sumatera.
\end{abstract}

Keywords: Foreign Investment (FI); Economic Growth

\section{PENDAHULUAN}

Berkembangnya perekonomian suatu negara, terutama negara berkembang seperti Indonesia dan daerah pada khususnya dapat dilihat dari tingkat pertumbuhan penanaman modal asing. Untuk meningkatkan devisa suatu negara diperlukan Penanaman Modal Asing agar memberikan keuntungan kepada semua pihak dan juga tempat modal itu ditanamkan serta negara asal investor. Menyadari pentingnya penanaman modal asing, Indonesia sebagai negara berkembang berupaya menumbuhkan iklim investasi yang kondusif guna menarik calon investor untuk menanamkan modalnya.

Penanaman modal asing diwilayah Indonesia adalah bentuk kewenangan pemerintah pusat yang kemudian diturunkan kepada kewenangan pemerintah daerah. Dimana pemerintah daerah harus selalu berkoordinasi dengan pemerintah pusat, untuk mewujudkan kesejahteraan bagi seluruh masyarakat daerah.

Kebijakan pemerintah daerah dalam penanaman modal asing merupakan bagian dari rencana pembangunan dan kerja pemerintah daerah, baik jangka panjang, menengah dan tahunan. Hal ini diatur dalam Undang-Undang Nomor 25 Tahun 2004 tentang sistem perencanaan pembangunan Nasional (SPPN) memberikan definisi bahwa rencana adalah proses untuk menentukan tindakan masa depan yang tepat melalui urutan pilihan dengan memperhitungkan sumber-sumber daya yang tersedia.

Pemberian urusan kepada daerah menurut sistem otonomi riil dilihat dari ketentuan Pasal 6 ayat 1 dan Pasal 9 ayat 2 Undang-Undang Nomor 22 Tahun 1999 tentang Pemerintahan Daerah. Salah satunya tentang pelayanan administrasi penanaman modal lintas kabupaten atau kota.

Kewenangan pemerintah yang diberikan kepada daerah dalam asas desentralisasi harus disertai penyerahan dan pengalihan pembinaan, sarana dan prasarana serta sumber daya manusianya. Untuk penerapannya memang otonomi itu dilaksanakan terlalu cepat sehingga membuat daerah-daerah tidak cukup siap, terutama bagi sumber daya manusianya.

Rencana pembangunan dalam hukum ditetapkan dalam Undang-Undang Nomor 17 Tahun 2007 tentang Rencana Pembangunan Jangka Panjang Tahun 2005-2025. Pembangunan hukum diarahkan untuk mendukung terwujudnya pertumbuhan ekonomi yang berkelanjutan dan mencipatakan kepastian investasi. ${ }^{1}$ Pengembangan ekonomi daerah harus berdasarkan prinsip keunggulan komparatif berorientasi kepada kompetensi dan produk unggulan di setiap daerah.

1 Donald Albert Rumokoy dan Frans Maramis. Pengantar Ilmu Hukum, PT. RajaGrafindo Persada, 2014, hlm.203. 
Alternatif penghimpunan dana pembangunan perekenomian Indonesia melalui investasi modal secara langsung jauh lebih baik dibandingkan dengan penarikan dana internasional lainnya seperti pinjaman luar negeri. ${ }^{2}$ Kegiatan investasi dapat memberikan dampak positif bagi negara penerima modal yaitu mendorong pertumbuhan bisnis, adanya supply teknologi dari investor baik dalam bentuk proses produksi maupun teknologi dan menciptakan lapangan kerja dalam sistem perekonomian yang berdaya saing.

Penananaman modal asing (foreign direct investment) memberikan banyak kelebihan satu diantaranya adalah memberikan andil dalam alih teknologi. ${ }^{3}$ Teknologi menjadi paradigma baru untuk menentukan kualitas suatu bangsa. Ungkapan bahwa "siapa yang menguasai teknologi akan menggenggam dunia ditangannya", untuk itu tidak diragukan lagi agar bisa disikapi secara bijaksana. Hubungan Teknologi dengan industrialisasi menjadi tolak ukur pertumbuhan ekonomi yang mencerminkan keberhasilan pembangunan suatu bangsa.

Penanaman modal asing merupakan cara untuk mempercepat pembangunan ekonomi kearah stabilitas dan pertumbuhan ekonomi, salah satunya dengan cara mendirikan perusahaan modal asing di Indonesia. Masuknya penanam modal asing di Indonesia maka Pemerintah daerah melakukan tindakan nasionalisasi perusahaan modal asing. Penanaman modal dianggap banyak menimbulkan dampak negatif bagi masyarakat baik terhadap pelanggaran HAM ataupun lingkungan. Hal ini merupakan pandangan yang mewakili kelompok "jalan tengah" (the middle path theory) yang memandang investasi asing selain bermanfaat (positif) juga menimbulkan dampak (negatif). Negara harus berperan untuk mengurangi dampak negatif melalui berbagai kebijakan hukum antara lain melalui penapisan (screening) dalam perizinan dan upaya sungguh-sungguh dalam penegakan hukum. ${ }^{4}$

Pemerintah provinsi Sumatera Selatanpun melakukan upaya untuk menarik investor agar melakukan kegiatan penanaman modal di Sumatera Selatan yang diharapkan dapat memberikan dampak positif untuk pengembangan dunia usaha daerah yang nantinya bermuara kepada peningkatan dan pemerataan kesejahteraan rakyat di Sumatera Selatan. ${ }^{5}$

${ }^{2}$ Yulianto Syahyu. Pertumbuhan Investasi Asing di Kepulauan Batam: Antara Dualisme Kepemimpinan dan Ketidakpastian Hukum, Jurnal Hukum Bisnis, Vol 22, No.5 Tahun 2003, hlm.46.

${ }^{3}$ Abdul Manan, Peranan Hukum Dalam Pembangunan Ekonomi, Jakarta:Kencana, 2014, hlm.101.

${ }^{4}$ Ida Bagus Rahmadi Supanca,Kerangka Hukum dan Kebijakan Investasi Langsung di Indonesia, hlm. 63.

${ }^{5}$ Handayani, Sri. 2011. Upaya Pemerintah Sumatera Selatan Menarik Investor Asing Dalam Kegiatan Penanaman

\section{Rumusan masalah}

Berdasarkan latar belakang tersebut, maka permasalahan yang akan dikaji dalam kajian hukum ini adalah peranan penanaman modal asing sebagai bentuk upaya peningkatan pertumbuhan ekonomi di Sumatera Selatan menuju Sumatera Selatan Maju.

\section{METODE}

Penelelitian ini merupakan penelitian yuridis empiris ${ }^{6}$. Istilah lain yang dipakai adalah penelitian indoktriner atau hukum sosiologi atau penelitian lapangan ${ }^{7}$. Pendekatan yang digunakan yaitu analitis (Analytical Apporach). Pendekatan analitis digunakan untuk mengetahui makna yang terkandung dalam istilah-istilah hukum baik dalam aturan hukum positif secara konseptual dan penerapannya dalam praktik. Bahan penelitian yang telah diperoleh baik bahan primer atau pun bahan sekunder dianalisa secara kualitatif. Adapun Teknik penarikan kesimpulan penelitian ini dilakukan secara induktif.

\section{HASIL DAN PEMBAHASAN}

Indonesia sebagai negara berkembang memerlukan dana yang cukup besar dan memadai untuk melakukan pembangunan ekonomi, dimana jalan keluarnya adalah mencari pinjaman luar negeri dan penanaman modal asing. Hal ini diatur dalam Undang-Undang Nomor 25 Tahun 2007 tentang Penanaman Modal yang selaras dengan tujuan Undang-Undang Dasar 1945. Undang-Undang Dasar 1945 menyebutkan tentang konspsi tanggung jawab negara dalam hak asasi manusia yang diatur dalam pasal 28 I ayat 4 dan 5 menyatakan

\begin{abstract}
"Perlindungan, pemajuan, penegakan, dan pemenuhan hak asasi manusia adalah tanggung jawab negara, terutama pemerintah dan untuk menegakkan dan melindungi hak asasi manusia sesuai dengan prinsip negara hukum yang demokratis, maka pelaksanaan hak asasi manusia dijamin, diatur, dan dituangkan dalam peraturan perundang-undangan."
\end{abstract}

Dasar tindakan bagi pemerintah dalam memajukan hak asasi manusia harus dapat dinilai dari pemikiran, perbuatan, ketika kaidah-kaidah hukum itu diberlakukan. Pemberlakuan kaidah hukum atas dasar kultur individu dan masyarakat adalah memberikan pengertian atas keberlakuan aturan hukum selaras dengan nilai-nilai yang

Modal, Fakultas Hukum Universitas Sriwijaya. Jurnal Dinamika Hukum, Vol 11 No 1.

${ }^{6}$ Usmawadi, Petunjuk Penulisan Ilmiah Bidang Hukum. Materi Pendidikan Latihan dan Kemahiran Hukum, Laboratorium Hukum Fakultas Hukum UNSRI, 1992, hlm. 250.

${ }^{7}$ Ibid., 
mendasari masyarakat di dalam pola tindakan dan tata kelakuan baik sebagai individu maupun sebagai anggota masyarakat. $^{8}$

\section{Pengertian Penanaman Modal Asing}

Penanaman modal asing bersal dari terjemahan bahasa inggris "foreign investment" yang berarti suatu kegiatan menanamkan modal di wilayah Negara Republik Indonesia baik menggunakan modal asing seutuhnya maupun beroatungan dengan modal dalam negeri. Undang-Undang Nomor 25 Tahun 2007 tentang Penanaman Modal menyatakan bahwa penanam modal asing adalah "perseroan warga negara asing, badan usaha asing, dan/atau pemerintah asing yang melakukan penanaman modal di wilayah Negara Republik Indonesia". selain itu penanaman modal asing di Indonesia adalah penanaman modal asing langsung yang mengurus dan mengelola modal asing sepenuhnya.

Dalam kaitan ini Sharpe sebagaimana dikutip oleh Nurul Huda dan Mustafa Edwin Nasution mengemukakan bahwa pada dasarnya ada beberapa tahapan dalam mengambil keputusan penanaman modal satu diantaranya adalah pembentukan portofolio, dimana pada tahap ini investor membentuk portofolio yang melibatkan identifiikasi aset khusus mana yang akan diinvestasikan dan juga menentukan seberapa besar investasi pada tiap aset tersebut. Disini masalah selektivitas, penentuan waktu dan diversifikasi perlu menjadi perhatian investor. ${ }^{10}$

Penanaman modal asing merupakan transfer modal, baik nyata maupun yang tidak nyata dari suatu negara ke negara lain, tujuannya digunakan negara tersebut agar menghasilkan keuntungan dibawah pengawasan dari pemilik modal, baik secara total maupun sebagian, hal ini sebagaimana dijelaskan oleh $M$. Sornarajah. ${ }^{11}$ Kategori dari pemilik modal asing meliputi:

(a) Negara asing;

(b) Perseorangan warga negara asing;

(c) Badan usaha asing;

(d) Badan hukum asing; dan

(e) Badan hukum Indonesia yang sebagian atau seluruh modalnya dimilki oleh pihak asing.

${ }^{8}$ Faried Ali, Anwar Sulaiman, dan Femmy Silaswati, Studi Sistem Hukum Indonesia: Untuk Kompetensi Bidang Ilmu-Ilmu Sosial dan Ilmu Politik dan dalam Payung Pancasila, Bandung:Refika Aditama, 2012, hlm.142.

${ }^{9}$ Salim dan Budi Sutrisno, Hukum Investasi di Indonesia, Jakarta:PT. RajaGrafindo Persada, 2008, hlm.147.

${ }^{10}$ Nurul Huda dan Mustafa Edwin Nasution, Investasi pada Pasar Modal Syariah, Jakarta:Prenadamedia Group, Jakarta, hlm. 9-10.

${ }^{11}$ M. Sornarajah, Hukum Investasi di Indonesia, Jakarta:PT.RajaGrafindo Persada, 2008, hlm.149.
Penanaman modal asing dalam Undang-Undang Nomor 25 Tahun 2007 terdapat dalam pertama bagian konsiderans "menimbang" huruf (c), yang memuat pertimbangan dibentuknya Undang-Undang Nomor 25 Tahun 2007 tentang penanaman Modal yaitu "untuk mempercepat pembangunan ekonomi nasional dan mewujudkan kedaulatan politik.." kedua, pada bagian Penjelasan Umum yang memuat penegasan bahwa Konstitusi Undang-Undnag Dasar Negara Kesatuan Republik Indonesia Tahun 1945 mengamanatkan agar pembangunan ekonomi nasional harus berdasarkan prinsip ekonomi yang mampu menciptakan terwujudnya kedaulatan ekonomi Indonesia dan ketiga, pada Pasal 3 ayat (1) huruf (i) yang mengandung asas kemandirian yang merupakan asas penanaman modal yang tetap mengedapankan potensi bangsa dan negara dan tidak menutup diri pada masuknya modalnya demi asing demi terwujudnya pertumbuhan ekonomi.

Perspektif Undang-Undang Nomor 25 Tahun 2007 tentang Penanaman Modal harus mengutamakan kesejahteraan rakyat Indonesia dengan cara mengedepankan potensi yang dimiliki oleh bangsa dan negara tanpa mengabaikan kedaulatan ekonomi dan kedaulatan politik Indonesia. ${ }^{12}$ Berdasarkan kebijakan dasar yang ditetapkan oleh pemerintah melakukan perlakuan yang sama kepada penanam modal, yaitu bahwa pemerintah tidak melakukan pembedaan terhadap penanam modal yang telah menanamkan modalnya di Indonesia kecuali ditentukan lain oleh ketentuan undang-undang. ${ }^{13}$ Sehubungan dengan otonomi daerah, maka pemerintah daerah dalam hal ini Sumatera Selatan berusaha untuk mengundang investor masuk dengan tujuan untuk meningkatkan perekenomian rakyat.

\section{Temuan dan Hasil}

Pemerintah Republik Indonesia semakin membuka diri agar masuknya modal asing demi mewujudkan pertumbuhan ekonomi. Undang-Undang Nomor 25 Tahun 2004 tentang Sistem Perencanaan Pembangunan Nasional (SPPN) mendefinisikan rencana adalah proses untuk menentukan tindakan masa depan yang tepat melalui urutan pilihan dengan memperhitungakan sumber-sumber daya yang tersedia. Tata cara perencanaan pembangunan untuk menghasilkan rencana-rencana pembangunan dalam jangka panjang, jangka menengah dan tahunan yang dilaksanakan oleh unsur penyelenggara negara dan masyarakat.

Tahapan penyusunan rencana dilaksanakan untuk menghasilkan rancangan lengkap suatu rencana yang siap

${ }^{12}$ Muhammad Syaifuddin, Nasionalisasi Perusahaan Modal Asing: Ide Normatif Pengaturan Hukumnya dalam UU No.25 Tahun 2007 dan Relevansinya dengan Konsep Negara Hukum Kesejahteraan Pancasila dalam UUD NRI Tahun 1945, Jurnal Hukum, hlm.9.

${ }^{13}$ Hendrik Budi Untung, Hukum Investasi, Jakarta: Sinar Grafika, 2010, hlm. 4. 
Dea Justicia Ardha, Peranan Penanaman Modal Asing Sebagai Upaya Peningkatan Petumbuhan Ekonomi di Sumatera Selatan Menuju Sumatera Selatan Maju

ditetapkan yang terdiri dari 4 langkah yaitu sebagai berikut:

1. Penyiapan rancangan rencana pembangunan yang bersifat teknokratik, menyeluruh dan terstrukur;

2. Masing-masing instansi pemerintah menyiapkan rancangan kerja dengan berpedoman kepada rancangan rencana pembangunan yang telah disiapkan;

3. Melibatkan masyarakat dan menyelaraskan rencana pembangunan yang dihasilkan masing-masing jenjang pemerintahan melalui musyawarah perencanaan pembangunan; dan

4. Penetapan rencana menjadi produk hukum sehingga mengikat semua pihak untuk melaksanakannya. ${ }^{14}$

Masalah yang dihadapi dalam mengembangkan perekonomian daerah adalah mengupayakan kelangsungan kegiatan usaha ekonomi yang ada agar berkembang dan lebih maju, dimulai dengan pengembangan efisiensi dan efektivitas manajemen. Disamping itu terdapat tantangan dalam memanfaatkan keunggulan geografis daerah untuk mengembangkan perekonomian yang berorientasi kepada pasar nasional, regional dan global dengan tetap memperhatikan daya dukung lingkungan dan kapasitas sumber daya alam.

Peningkatan investasi di Sumatera Selatan terutama dari luar negeri dibutuhkan institusi yang kuat, agar dapat melahirkan pola kepemimpinan yang mendukung kebijakan-kebijakan investasi. Untuk itu, yang harus dilakukan adalah membuat kebijakan reformasi birokrasi sebagai prioritas perbaikan iklim investasi, diantaranya dengan penyederhanaan sistem dan perizinan usaha, penurunan berbagai pungutan atau pajak yang tumpang tindih, serta transparansi biaya perizinan. Hal lain yang harus mendapatkan penekanan adalah melakukan evaluasi dan review atas pemetaan lokasi investasi, sehingga menghadirkan instrumen kebijakan yang sinergis antara Pemerintah Pusat dan Daerah menjadi aspek penting, mengingat tumpang tindihnya Peraturan Pusat dan Daerah akan berimplikasi pada terhambatnya arus barang dan jasa tetapi juga menciptakan iklim usaha yang tidak sehat. ${ }^{15}$

Melalui Undang-Undang Nomor 32 Tahun 2004 hubungan pemerintah daerah provinsi dengan pemerintah daerah dapat direkatkan kembali. Hubungan tersebut diantaranya adalah hubungan pemanfaatan sumber daya alam. Sejauh ini, sektor perkebunan dan pertambangan hampir mendominasi hampir $70 \%$ lebih dari total Penanam Modal Dalam Negeri (PMDN) maupun Penanam Modal Asing (PMA) yang ada di Sumatera

\footnotetext{
${ }^{14}$ W. Riawan Tjandra, Hukum Sarana Pemerintahan, Yogyakarta:Cahaya Atma Pustaka, 2014, hlm.47.

15 Sri Handayani, Upaya Pemerintah Sumatera Selatan Menarik Investor Asing dalam Kegiatan Penanaman Modal, Jurnal, hlm.67,
}

Selatan. ${ }^{16}$ Sepanjang tahun 2018, penanaman modal asing masih mendominasi investasi di Sumatera Selatan.

Total realisasi investasi yang sudah masuk dari perusahaan yang sudah ada di Sumatera Selatan saat ini Rp.3,353 T berasal dari Penanam Modal Dalam Negeri (PMDN) dan Rp 12,922T berasal dari Penanam Modal Asing (PMA). Pada tahun 2019, penanaman modal asing di Provinsi Sumatera Selatan diyakini akan terus meningkat seiring positifnya prospek perekonomian di Indonesia. ${ }^{17} \mathrm{Hal}$ ini sebagaimana diperkuat oleh pendapat Gubernur Bank Indonesia menyatakan bahwa keyakinan itu didukung adanya upaya pemerintah untuk meningkatkan arus Penanam Modal Asing (PMA) guna meningkatkan investasi selain itu regulasi pemerintah juga mendorong Penanam Modal Asing (PMA).

Konsep negara hukum kesejahteraan menunjukkan bahwa pemerintah memperbolehkan dilakukannya penanaman modal asing dalam upaya mewujudkan kesejahteraan bagi rakyat provinsi Sumatera Selatan dalam rangka menjunjung tinggi harkat dan martabat kemanusia Indonesia sebagai mahluk tuhan yang Maha Esa, dengan tetap memperhatikan tujuan dari dilakukannya penanaman modal asing diantaranya untuk menegakan kedaulatan ekonomi dan kedaulatan politik serta tetap mengedepankan potensi bangsa dan negara yang dapat mencerminkan kemandirian bangsa Indonesia sebagaimana asas kemandirian yang dianut dalam ketentuan Pasal 3 ayat (1) huruf (i) Undang-Undang nomor 25 Tahun 2007 tentang Penanaman Modal.

Pemerintah provinsi Sumatera Selatan terus berupaya keras untuk mempertahankan nilai investasi yang sudah melampaui target. Meningkatkan investasi ke Provinsi Sumatera Selatan tidak lepas dari pelayanan terbaik yang diberikan oleh Pemerintah Provinsi Sumatera Selatan kepada calon investor, sehingga mengakibatkan hampir semua asset kebanjiran dana asing hal ini menunjukan kepercayaan investor terhadap Sumatera Selatan. Selain itu dipengaruhi oleh prospek ekonomi yang lebih baik di tahun 2019 dan Sumatera Selatan juga menetapkan PTSP yaitu pelayanan terpadu satu pintu untuk para investor yang ingin berinvestasi.

Sumatera Selatan berusaha menjadi wadah yang tepat untuk pertumbuhan dan perkembangan investasi dengan regulasi dan kebijakan yang berdasarkan ke otentikan suatu daerah yang bersangkutan berdasarkan sumber daya manusia, sumber daya alam, kelembagaan dan tekhnologi. Munculnya para pesaing juga menjadi

\section{Sumsel,}

${ }^{16}$ Sepanjang 2018, PMA Masih Dominasi Investasi di https://www.detiksumsel.com/sepanjang-2018-pma-masih-do minasi-investasi-di-sumsel/, diakses pada 17 April 2019.

\section{Sumsel,}

${ }^{17}$ Sepanjang 2018, PMA Masih Dominasi Investasi di

https://www.detiksumsel.com/sepanjang-2018-pma-masihdominasi-investasi-di-sumsel/, diakses pada 17 April 2019. 
Dea Justicia Ardha, Peranan Penanaman Modal Asing Sebagai Upaya Peningkatan Petumbuhan Ekonomi di Sumatera Selatan Menuju Sumatera Selatan Maju

beban tugas yang berat bagi pemerintahan Sumatera Selatan. Beban tugas yang harus dipikul adalah menyiapkan daerahnya sedemikian rupa sehingga mampu menjadi wadah bagi pertumbuhan dan perkembangan investasi sekaligus memasarkannya kepada dunia luar secara sistematis, strategis dan efisien.

\section{SIMPULAN}

Kegiatan penanaman modal asing yang dilaksanakan oleh pemerintah Sumatera Selatan terlebih dahulu telah ada koordinasi dengan pemerintah pusat. Pemerintah pusat mendistribusikan kewenangan kepada pemerintah daerah. Oleh karena itu pengembangan ekonomi Sumatera Selatan yang sudah semakin membaik perlu didasarkan kepada prinsip keunggulan komparatif berorientasi kepada kompetensi dan produuk unggulan.

Pemerintah Provinsi Sumatera Selatan saat ini berada dalam posisi membuka diri untuk penanaman modal asing dalam upaya untuk menegakkan kembali kedaulatan ekonomi dan kedaulatan politik sehingga dapat menciptakan kesejahteraan masyarakat di Sumatera Selatan. Sebagaimana relevansinya dengan konsep Negara Hukum Kesejahteraan, dimana dalam melakukan penanaman modal asing, Pemerintah Provinsi Sumatera Selatan tidak mengabaikan potensi dalam negeri sesuai asas kemandirian yang merupakan salah satu asas penanaman modal yang diatur dalam ketentuan Pasal 3 ayat (1) huruf (i) Undang-Undang Nomor 25 Tahun 2007 tentang Penanaman Modal.

Faktor yang harus menjadi pertimbangan melakukan penanaman modal asing oleh Pemerintah Provinsi Sumatera Selatan dalam kaitannya dengan instrumen perencanaan sebagai dasar penyelenggaraan negara dapat dijadikan perbandingan dan pembelajaran bagi Pemerintah Provinsi Sumatera Selatan bahwa dalam melakukan penanaman modal asing hendaknya bertujuan untuk memulihkan kedaulatan ekonomi dan politik atas sumber daya alamnya. Penanaman modal asing bertujuan untuk menarik penanaman modal asing guna mendukung pembangunan ekonomi, tanpa mengabaikan potensi penanaman modal dalam negeri. Pembangunan nasional dalam upaya untuk mewujudkan pembangunan ekonomi di Sumatera Selatan harus dilaksanakan dengan prinsip kemandirian.

Pembangunan nasional dimaksudkan bahwa pembangunan yang dilaksanakan dari waktu ke waktu sedapat mungkin dapat dibiayai oleh dana bangsa Indonesia sendiri. Dengan tetap mempertahankan asas kemandirian yang diatur dalam ketentuan Pasal 3 ayat (1) huruf (i) Undang-Undang Nomor 25 Tahun 2007 tentang Penanaman Modal.

\section{Saran}

Agar Penanaman Modal Asing dapat dilaksanakan sejalan dengan tujuan yang hendak dicapai, maka pemerintah Sumatera Selatan wajib melakukan pembinaan berupa pemberian pedoman satu perencanaan.
Kegiatan penanaman modal asing yang dilaksanakan oleh pemerintah daerah telah disetujui pemerintah pusat sebab, dikhawatirkan bahwa langkah ini dapat membuat rakyat Sumatera Selatan semakin miskin, semakin menderita, dan semakin tingginya jurang antara si kaya dan si miskin, kekayaan alam Indonesia makin terkuras habis tanpa memberikan kesejahteraan bagi seluruh rakyat Sumatera Selatan sesuai dengan amanat Undang-Undang Dasar Negara Kesatuan Republik Indonesia Tahun 1945.

\section{DAFTAR PUSTAKA}

Abdul Manan. 2014. Peranan Hukum Dalam Pembangunan Ekonomi, Jakarta: Kencana.

Donald Albert Rumokoy dan Frans Maramis. 2014. Pengantar Ilmu Hukum, PT. Raja Grafindo Persada.

Faried Ali, Anwar Sulaiman, dan Femmy Silaswati. 2012. Studi Sistem Hukum Indonesia: Untuk Kompetensi Bidang Ilmu-Ilmu Sosial dan Ilmu Politik dan dalam Payung Pancasila, Bandung: Refika Aditama.

Hendrik Budi Untung. 2010. Hukum Investasi, Jakarta: Sinar Grafika.

Ida Bagus Rahmadi Supanca, Kerangka Hukum dan Kebijakan Investasi Langsung di Indonesia.

I Wibowo, Emoh Negara: Neoliberalisme dan Kampanye Anti-Negara,dalam I Wibowo dan Prancis Wahono,ed., Neoliberalism.

M. Sornarajah. 2008. Hukum Investasi di Indonesia, Jakarta: PT Raja Grafindo Persada.

Salim dan Budi Sutrisno. 2008. Hukum Investasi di Indonesia, Jakarta: PT Raja Grafindo Persada.

Muhammad Syaifuddin, Nasionalisasi Perusahaan Modal Asing: Ide Normatif Pengaturan Hukumnya dalam UU No.25 Tahun 2007 dan Relevansinya dengan Konsep Negara Hukum Kesejahteraan Pancasila dalam UUD NRI Tahun 1945, Jurnal Hukum.

Nurul Huda dan Mustafa Edwin Nasution. Investasi pada Pasar Modal Syariah, Jakarta: Prenadamedia Group.

Salim dan Budi Sutrisno. 2008. Hukum Investasi di Indonesia, Jakarta: PT Raja Grafindo Persada.

Sri Handayani, 2011. Upaya Pemerintah Sumatera Selatan Menarik Investor Asing Dalam Kegiatan Penanaman Modal, Fakultas Hukum Universitas Sriwijaya. Jurnal Dinamika Hukum, Vol 11 No 1.

Usmawadi. 1992. Petunjuk Penulisan Ilmiah Bidang Hukum. Materi Pendidikan Latihan dan Kemahiran Hukum, Laboratorium Hukum Fakultas Hukum UNSRI.

W. Riawan Tjandra. 2014. Hukum Sarana Pemerintahan, Yogyakarta:Cahaya Atma Pustaka.

Yulianto Syahyu, Pertumbuhan Investasi Asing di Kepulauan Batam: Antara Dualisme Kepemimpinan dan Ketidakpastian Hukum, Jurnal Hukum Bisnis, Vol 22, No.5 Tahun 2003. 